\title{
Information flow to increase support for tidal energy development in remote islands of a developing country: agent-based simulation of information flow in Flores Timur Regency, Indonesia
}

\author{
Rohit Ramachandran ${ }^{1 *} \mathbb{D}$, A. H. T. Shyam Kularathna ${ }^{1}$, Hirotaka Matsuda ${ }^{2}$ and Ken Takagi ${ }^{3}$
}

\begin{abstract}
Background: Public awareness is crucial for successful deployment of tidal energy, a renewable energy source that can provide clean electricity to remote islands. However, considering public attitudes on tidal energy are not well known, especially in developing countries, a barrier exists in implementing public engagement strategies. This study aims to contribute by identifying strategies for information provision — the initial step in public engagement—and estimate how these can be engaged to enhance support for tidal energy among the local public in a remote area of a developing country, in this case, Flores Timur Regency, Indonesia, considering their socio-cultural background.

Methods: In this paper, we employ statistical analyses using multinomial probit modelling to identify the key variables that shape information flow. The aptness of the variables is then verified using post-estimation techniques for their use as input parameters for the simulation of the information flow in the field study area. Agent-based simulation (ABS) is employed to replicate the actual conditions in Flores Timur Regency, Indonesia, and simulate the flow of information through the local community.
\end{abstract}

Results: According to the multinomial probit estimations, the people belonging to the top hierarchical group show a higher probability to support tidal energy compared to the members belonging to the lower groups. Understandably, around twice as many information flow cycles are needed to disseminate information to the members of the lowest hierarchical group, compared to the members of the top hierarchical group. The results also show that increasing the amount of available information has a positive impact on information dissemination.

Conclusions: This study demonstrated that information provision is highly effective with propagation of information that specifically highlights the individual benefits, rather than the community benefits of tidal energy. Additionally, savings in terms of costs, time, and efforts can be realized if the most influential members of the local community are targeted initially before including all other stakeholders. The study also indicated that locals absorb more information

\footnotetext{
*Correspondence: ramachandran.rohit@gmail.com

${ }^{1}$ Graduate Program in Sustainability Science-Global Leadership Initiative (GPSS-GLI), Graduate School of Frontier Sciences, The University of Tokyo, Room 334, Building of Environmental Studies, 5-1-5 Kashiwanoha, Kashiwa, Chiba 277-8563, Japan

Full list of author information is available at the end of the article
} permits use, sharing, adaptation, distribution and reproduction in any medium or format, as long as you give appropriate credit to the original author(s) and the source, provide a link to the Creative Commons licence, and indicate if changes were made. The images or other third party material in this article are included in the article's Creative Commons licence, unless indicated otherwise in a credit line to the material. If material is not included in the article's Creative Commons licence and your intended use is not permitted by statutory regulation or exceeds the permitted use, you will need to obtain permission directly from the copyright holder. To view a copy of this licence, visit http://creativecommons.org/licenses/by/4.0/. The Creative Commons Public Domain Dedication waiver (http://creativeco mmons.org/publicdomain/zero/1.0/) applies to the data made available in this article, unless otherwise stated in a credit line to the data. 
and increase their support for tidal energy when additional data is made available. Finally, as long-term strategy, information provision becomes most effective when the local population gains higher educational capabilities.

Keywords: Tidal energy, Public support, Information flow, Social hierarchy, Multinomial probit, Agent-based simulation, Developing country, Indonesia

\section{Background}

As widely recognized, fossil fuel usage for energy production is one of the main factors accelerating climate change, the most ominous threat globally [1]. Furthermore, use of renewable energy technologies contributes to climate change mitigation and disaster risk reduction, as highlighted in Goal 7 of the Sustainable Development Goals (SDGs) that promotes affordable and clean energy by all the member states of United Nations. According to the latest data about the progress towards SDG 7 , stepped-up efforts towards all targets were urgently required if SDG 7 should be reached within the coming decade [2]. Tidal current energy is a new technology that can provide clean renewable energy and contribute to successfully attaining SDG 7. Tidal current energy can be considered superior to other renewable energy sources such as wave power or wind power, as it is less susceptible to severe weather events such as typhoons or storms and, compared to those sources, tidal currents are a regular and predictable source of energy $[3,4]$. With several tidal projects under development in various parts of the world [5] there is an urgent need to address certain research areas. While there are many studies focusing on the technological [6-9], environmental [10,11], and economic $[10,12-15]$ aspects of tidal energy, there are only a few studies dealing with the social aspects [16]. This is expected as tidal technology is relatively new and has not yet been implemented commercially leading to relatively scarce information about, especially among the general public.

Additional studies on social aspects are needed as large-scale renewable energy projects can only be successful with the understanding and support of the local public [17], highlighting the importance of public participation. Moreover, with many businesses involved in tidal energy development, the role of the private sector in public engagement remains unclear, emphasizing an urgent research need that needs to be addressed.

Most of the public participation strategies can be classified into three main categories: (i) information provision, (ii) consultation, and (iii) engagement [18]. Logically however, the last two strategies can be successful and efficient, only after the first strategy has been effectively implemented. Strategies focusing on consultation processes, whereby the public is formally allowed to voice their opinion, can only be effective if the public is sufficiently and correctly informed of all the related aspects of tidal energy, as it has been found that the public can form opinions inconsistent with prior scientific studies in case of offshore renewable energy [19]. Likewise, the engagement methods, when the public is involved in each stage of development, are bound to failure without adequately knowledgeable members. Providing information about benefits and disadvantages of the project at an early stage allows people time to think about the issues, consider implications, and formulate their views. An informed public will understand the trade-offs, be able to contribute meaningfully to project design, and have greater trust with the project proponent [20].

The importance of information provision is emphasized more if the awareness level of the local population is relatively low, for example in remote isolated islands in developing countries where favourable conditions for tidal energy development persist as revealed by Ramachandran et al. [21]. Therefore, when it is related to a new technology such as tidal energy, most aspects of which are largely unknown to the general public, information provision is not only the initial process for public engagement, but also the most vital.

For efficient information provision, the developers and policy makers need to ascertain how and when the information has to be disseminated for spreading it effectively throughout the community [22]. The developers not only have to identify the type of information to be diffused, but also the fastest and most efficient way considering the associated costs, time and effort [23]. Moreover, information dissemination should be tailored to the predilection of the intended audience, i.e. the local community. Hence, the study of the community, including its demography, its social structures, and local information preferences is paramount for the information dissemination process to be successful.

To provide a unique voice toward tidal energy development, this study focuses on the information flow for promotion of tidal energy in a remote isolated area of a developing country. This research adds on to the previous study by Ramachandran et al. [21] which estimated the support for tidal energy based on information provision, identified the key factors that impact information provision in the local community, and explored the impact of information provision for developing countries compared to advanced nations. This study also directly 
contributes to the agenda for social research in marine renewable energy [16] by focusing on the communication and knowledge flow in the community and supplements the previous study by Ramachandran et al. [21] by identifying the most efficient strategies for information provision.

This study uses multinomial probit regression model to estimate the probability of support for tidal energy in Flores Timur Regency as well as verify the aptness of the key variables identified in the previous study [21]. After the suitability of the variables is confirmed, the variables are used as input parameters for agent-based simulation (ABS). ABS, an ideal methodology to replicate social systems, is used in this study to simulate the flow of information in a remote local community in a developing country to increase support for tidal energy, reflecting the unique nature of their society, and the type of information that is preferable to them. The key factors affecting the information flow and the ideal strategies for information provision that can be used by the developers to increase support for tidal energy are explored in this study. The subsequent sections describe the study area, followed by explanation of the methods used for this study. The results are then described, before the discussion of key findings, and the study's conclusions and limitations.

\section{Study area}

The limited studies focusing on the socio-economic or developmental aspects of tidal energy are based mostly in advanced countries, highlighting a need for case studies from developing areas. There are many areas in developing countries such as Indonesia, where there is tremendous potential for tidal energy [24, 25]. Moreover, many areas with potential for tidal energy generation lie in remote locations, such as isolated islands. Larantuka strait in Flores Timur, a far-flung regency in Nusa Tenggarah Timur province in south-east Indonesia is one of the most favourable locations for tidal energy generation. Larantuka Strait is about $8 \mathrm{~km}$ in length. The north and south inlets of Larantuka Strait are both around $4.5 \mathrm{~km}$ wide. Meanwhile, at the narrowest part, the width of the strait is approximately $600 \mathrm{~m}$ and the depth is $20 \mathrm{~m}$ [26]. These conditions provide Larantuka strait with high potential for tidal energy generation [27-33]. While Larantuka strait is the potential site of the tidal energy project, entire Flores Timur Regency is selected as the study area, as its population will be the major direct beneficiary of the project. This study adds on to the previous study by Ramachandran et al. [21] examining the public acceptance of tidal energy in Flores Timur Regency.

The population in Flores Timur Regency is spread over 250 villages in the three habited islands of Flores, Adonara, and Solor, with the regency capital based in
Larantuka in Flores. The social stratification in Flores Timur, with an active traditional structure, is highly prominent. The leaders of Koten, Kelen, Hurint and Maran clans maintain a revered place at the top of the hierarchy, followed by leaders of other clans and village elders [21]. Not only are the social structures made of at least four hierarchical levels, the governmental administrative bodies as well as the prominent religious institutions also display a hierarchical nature, with four or more stratifications. Based on interviews with the local community members and local government officials, it was identified that the social structure of the community is significant for all communications, as the information flow follows the top-down hierarchy [21]. This study considers the population of Flores Timur Regency, with its hierarchical society in replicating the flow of information, in relation to tidal energy development. The study also considers two types of information that may impact the public view on tidal energy. Statistical results of Ramachandran et al. [21] show that the local people in Flores Timur Regency tend to show more support for tidal energy if their preference is for information related to individual benefits of tidal energy, as opposed to the information about collective benefits of tidal energy.

\section{Methods}

The support for tidal energy based on information provision is simulated according to the framework shown in Fig. 1.

Two kinds of simulation models are employed here: multinomial probit model and agent-based simulation (ABS) model. In the first simulation, multinomial probit regression modelling is used to estimate the probable number of supporters of tidal energy based on the information preferences, the demographical features, and the social structure of the local community. The output of the multinomial probit model is then used to create input parameters for the second simulation, the ABS model for information dissemination. Post-estimation techniques are then used to authenticate the suitability of the key variables to be used as input parameters for ABS, as has been employed in several studies [34]. As part of the post-estimation treatments, the variables are then distributed in hierarchical groups that represent the social structure of Flores Timur Regency, and the probability of each group to support tidal energy is estimated. Finally, the information flow in the local community is simulated using agent-based simulation (ABS) and the number of cycles required to provide information to the probable number of supporters of tidal energy is tallied for each hierarchical group based on the type of information. 
Simulation I: Probability of Support

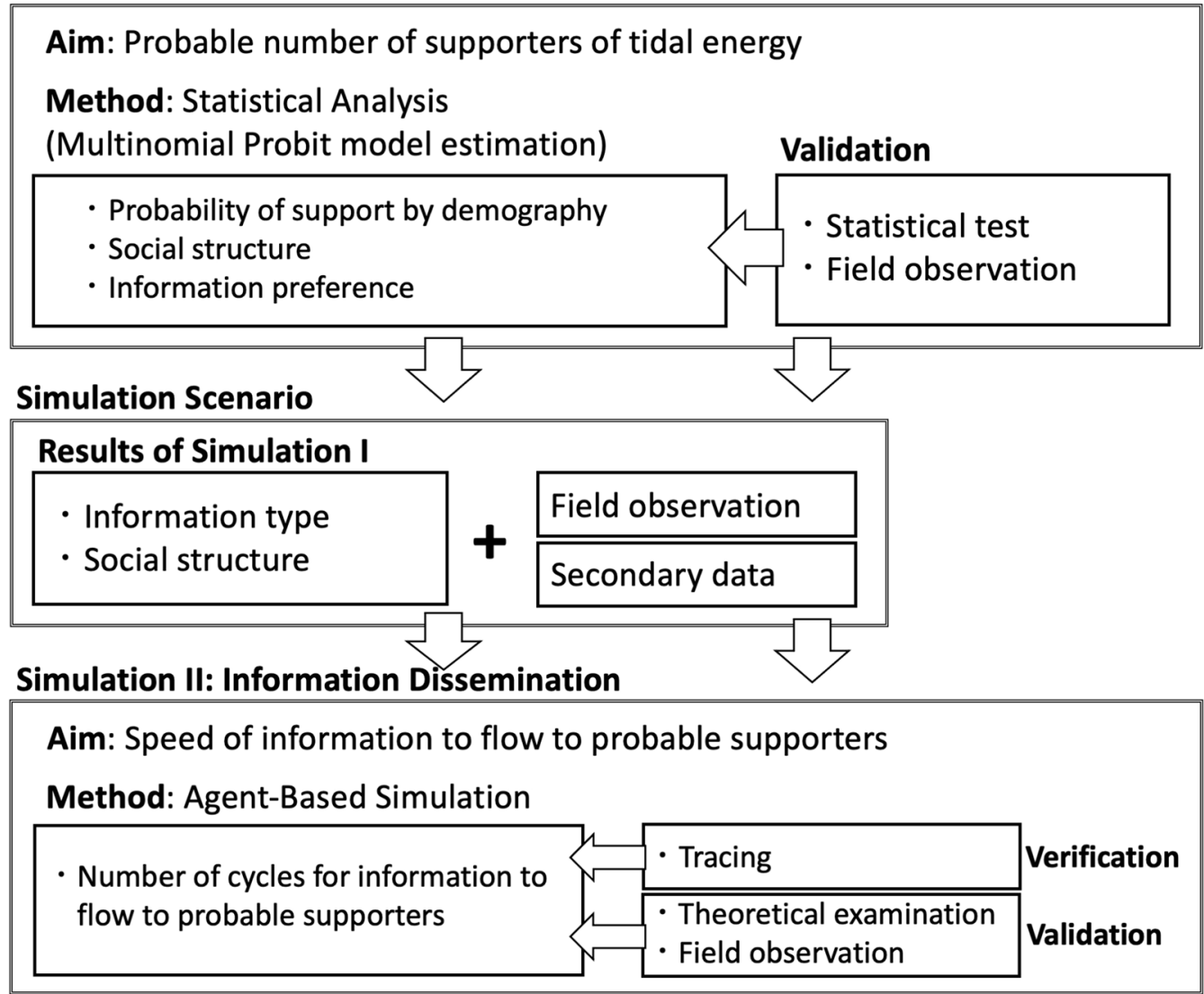

Fig. 1 Framework for estimating support for tidal energy based on information provision

\section{Step I: multinomial probit model estimation}

The multinomial probit model, one of the most satisfactory choices for discrete choice modelling [35], is used to estimate the probability of support for tidal energy and is derived from the data and results presented in the previous article by Ramachandran et al. [21]. The data were collected from 135 respondents using questionnaires presented to residents, selected at random, from villages spread over the three major islands in Flores Timur Regency. The key variables as identified in the previous study, and used here for further analysis are described in Table 1.

The multinomial probit model is then put through post-estimation techniques to verify the suitability of the variables for reflecting the actual situation in the case study area, and to be used as input parameters for the simulation.

The post-estimation techniques and the simulation processes are described below.

\section{Post-estimation measures}

After estimating the probability of support, two postestimation measures are used to check the viability of the variables: goodness-of-fit and receiver operating characteristic (ROC) curves.

The key goodness-of-fit measure used here is Count $R$-squared. Count $R$-squared transforms the continuous predicted probabilities into a binary variable on the same scale as the outcome variable and then assesses the predictions as correct or incorrect [36]. The $R$-squared is this correct count divided by the total count; $R$-squared values greater than 0.5 suggest a good fit.

To further confirm the appropriateness of the variables, receiver operating characteristic (ROC) curves are also employed. In analysis for count data such as probit regression, ROC curves are very useful for evaluating the predictive accuracy of a chosen model [37]. For ROC curve, the predicted values generated by the probit model can be viewed as a continuous indicator to be compared to the observed response variable. ROC curves can be best interpreted by creating a graph using the variables to have a good visual representation of their accuracy. Additionally, a numerical measure of the accuracy can be obtained by calculating the area under the ROC curve, 
Table 1 Description of variables

\begin{tabular}{|c|c|c|}
\hline Variable & Description & Response scale \\
\hline Collective outcome favourability & $\begin{array}{l}\text { Respondent's inclination towards supporting initiatives } \\
\text { that focus on collective benefits of tidal energy }\end{array}$ & $\begin{array}{l}0 \text {-disagree } \\
1 \text {-neither agree nor disagree } \\
2 \text {-agree }\end{array}$ \\
\hline Individual outcome favourability & $\begin{array}{l}\text { Respondent's inclination towards supporting initiatives } \\
\text { that focus on individual benefits of tidal energy }\end{array}$ & $\begin{array}{l}0 \text {-disagree } \\
1 \text {-neither agree nor disagree } \\
2 \text {-agree }\end{array}$ \\
\hline Education & Education level of respondent & $\begin{array}{l}\text { 1-no formal education } \\
\text { 2-primary school } \\
\text { 3-junior high school } \\
\text { 4-senior high school } \\
\text { 5-bachelors degree } \\
6 \text { - masters degree }\end{array}$ \\
\hline Age & Age of respondent & $\begin{array}{l}1-15 \text { to } 24 \\
2-25 \text { to } 34 \\
3-35 \text { to } 44 \\
4-45 \text { to } 54 \\
5-55 \text { to } 64 \\
6-\text { over } 64\end{array}$ \\
\hline
\end{tabular}

with the resulting values above 0.5 pointing to the accuracy of the variable.

\section{Probability at specific values}

The variables employed in the multinomial probit cannot be used as the input parameters for the ABS in the current form. The values for age and education variables in the multinomial probit model, ranging from one to six, can be directly used in ABS to indicate the demographic aspects. But the variables for individual outcome favourability and collective outcome favourability in same multinomial probit model, with values ranging from zero to two, need to be modified for use in ABS to correspond to the spreading of different types of information: information about individual benefits and information about collective benefits of tidal energy.

Normally, multinomial probit modelling uses the average response values of the variables of the entire sample to estimate the predicted probabilities. However, the social hierarchies consisting of four hierarchical groups that are observed in the society in Flores Timur have to be replicated within the ABS model with each hierarchical group having separate input values for each variable rather than the overall mean value of the entire sample. To account for the above conditions, multinomial probit is employed again to estimate the probability to support tidal energy when specific variable values are assigned to each of the four hierarchical groups as observed in Flores Timur Regency [21].

\section{Simulation scenario}

As described in Fig. 1, scenarios are created using the results from multinomial probit model. Accordingly, three cases are created to reflect the wide range of values for the four variables: individual outcome favourability, collective outcome favourability, age, and education in the local society. Based on field observation of the hierarchical nature of the society and secondary data based on census that show the economic disparity between different classes, specific values then are assigned to the variables with the assumption that these values capture the specific social features to create an accurate representation of the local society of Flores Timur Regency. After specific values are assigned to the variables, multinomial probit is used to provide the predicted probability of each hierarchical group to support tidal energy, under the three cases. Once the support probabilities are estimated and the probable number of supporters under each case and hierarchical group is deduced, the next simulation process, agent-based simulation (ABS), is employed to simulate the number of cycles required for information to flow to the probable supporters of tidal energy.

\section{Step II: agent-based simulation (ABS)}

Agent-based simulation (ABS) engages independent agents operating within a spatial grid that represents the agents' environment. Each cell (patch) in the grid representing a geographical space where the agent resides, and each agent, run a particular set of rules and instructions that describe how they interact with other cells or agents. The macro-behaviour of the system may look different compared to the individual behaviour of the agents [38].

$\mathrm{ABS}$ is a good choice for the present research because the information sharing process being studied takes place between individual people (agents), and it is easy to see 
the spatial grid as representing the agent's location within the community. Rules can be used to describe how stakeholders decide how to harvest or share information, and the outcomes of interactions between agents. Hence ABS can be seen an alternate way to replicate and describe social phenomenon as pointed out by Epstein and Axtell [39].

Moreover, ABS is an appropriate methodology to study occurrences that may transpire only in the future [4044]. Additionally, with the study area being remote and isolated, $\mathrm{ABS}$ is an efficient and practical methodology to employ for conducting research. This study will use ABS to study the flow of information through the local community of Flores Timur Regency, respecting the structure of the community and the hierarchical rules of the society, for successful deployment of tidal energy.

\section{The ABS model for information flow}

Information flow models have relied on certain specific aspects to investigate the spread of information, for example, the mode of information diffusion [45] or the role of influential stakeholders [46]. This model follows the approach similar to those employed by Wilensky [47] and Huang et al. [48] for their models. In this simulation model, the agents exist in a two-dimensional space, consisting of 2500 cells or patches, with an agent occupying each cell, with the proximity of two agents representing geographical distance. According to Allen [49], the physical proximity has an indirect relationship on the probability of agents communicating, and this is reflected in the model where agents who are close together are more likely to interact. The model uses spatial proximity, defined here as 'visibility range' to determine the vicinity where a given individual can seek information from or spread it to other agents. The results of the model simulations show the fastest and the most efficient way to and processes governing this $\mathrm{ABS}$ model are described below.

\section{Agent behaviour}

In our model, agents choose among two alternatives to absorb information: (i) From a valid neighbouring agent who has more information than itself or (ii) from its residing cell if information harvesting is allowed and the cell has more information than the agent itself. The behaviour of the agents as assumed in this study is shown in Fig. 2.

Information harvesting from the environment (residing cell) is defined according to Eqs. (1) and (2). The glossary of terms used to denote the harvesting and sharing procedures are presented in Table 2.

$$
\begin{aligned}
& H_{C_{i, t}}=\left\{\begin{array}{ll}
\left(C_{i_{i, t}}^{\mathrm{cell}}-C_{i_{i, t}}^{\mathrm{agent}}\right) * A_{i} * E_{i} * C_{i_{H, i}} / 36 ; & C_{i_{i, t}}^{\mathrm{cell}}>C_{i_{i, t}}^{\mathrm{agent}} \\
0 ; & \text { Otherwise }
\end{array},\right. \\
& H_{I_{i, t}}=\left\{\begin{array}{ll}
\left(I_{i_{i, t}}^{\text {cell }}-I_{i_{i, t}}^{\text {agent }}\right) * A_{i} * E_{i} * I_{i_{H, i}} / 36 ; & I_{i_{i, t}}^{\text {cell }}>I_{i_{i, t}}^{\text {agent }} \\
0 ; & \text { Otherwise }
\end{array} .\right.
\end{aligned}
$$

At each time step or cycle, if harvesting is allowed, each agent's information levels are updated according to Eqs. (3) and (4):

$$
\begin{aligned}
& C_{i_{i, t+1}} \text { agent }=C_{i_{i, t}}^{\text {agent }}+H_{C_{i, t}}, \\
& I_{i, t+1}^{\text {agent }}=I_{i_{i, t}}^{\text {agent }}+H_{I i, t} .
\end{aligned}
$$

Information sharing among valid neighbouring agents is defined according to Eqs. (5) and (6). Selection of the neighbouring agent is directed according to the hierarchy level of the considered agent, level of information held and the visibility range.

$$
\begin{aligned}
& S_{C_{i}, j, t}=\left\{\begin{array}{cc}
\left(C_{i_{i, t}}^{\text {agent }}-C_{i_{j, t}}^{\text {agent }}\right) * F_{i} * S_{C_{i}} * A_{j} * E_{j} * C_{i_{R, j}} / 36 ; & C_{i_{i, t}}^{\text {agent }}>C_{i_{j, t}}^{\text {agent }} \\
0 ; & \text { Otherwise }
\end{array}\right.
\end{aligned}
$$

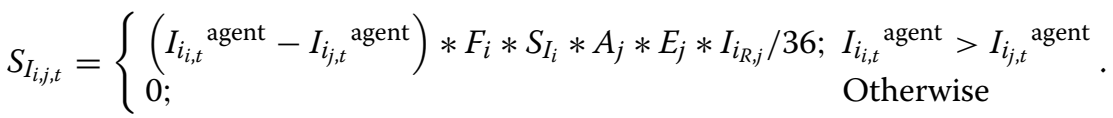

spread information in the local community.

In $\mathrm{ABS}$, the major simulation processes rely on the interaction between different agents, the interaction between the agent and the environment, and the rules guiding these interactions. The behaviours, interactions,
At each time cycle, if spreading is allowed, each agent's information levels are updated according to Eqs. (7) and (8):

$$
C_{i_{j, t+1}}^{\text {agent }}=C_{i_{j, t}}^{\text {agent }}+S_{C_{i, j, t}}
$$




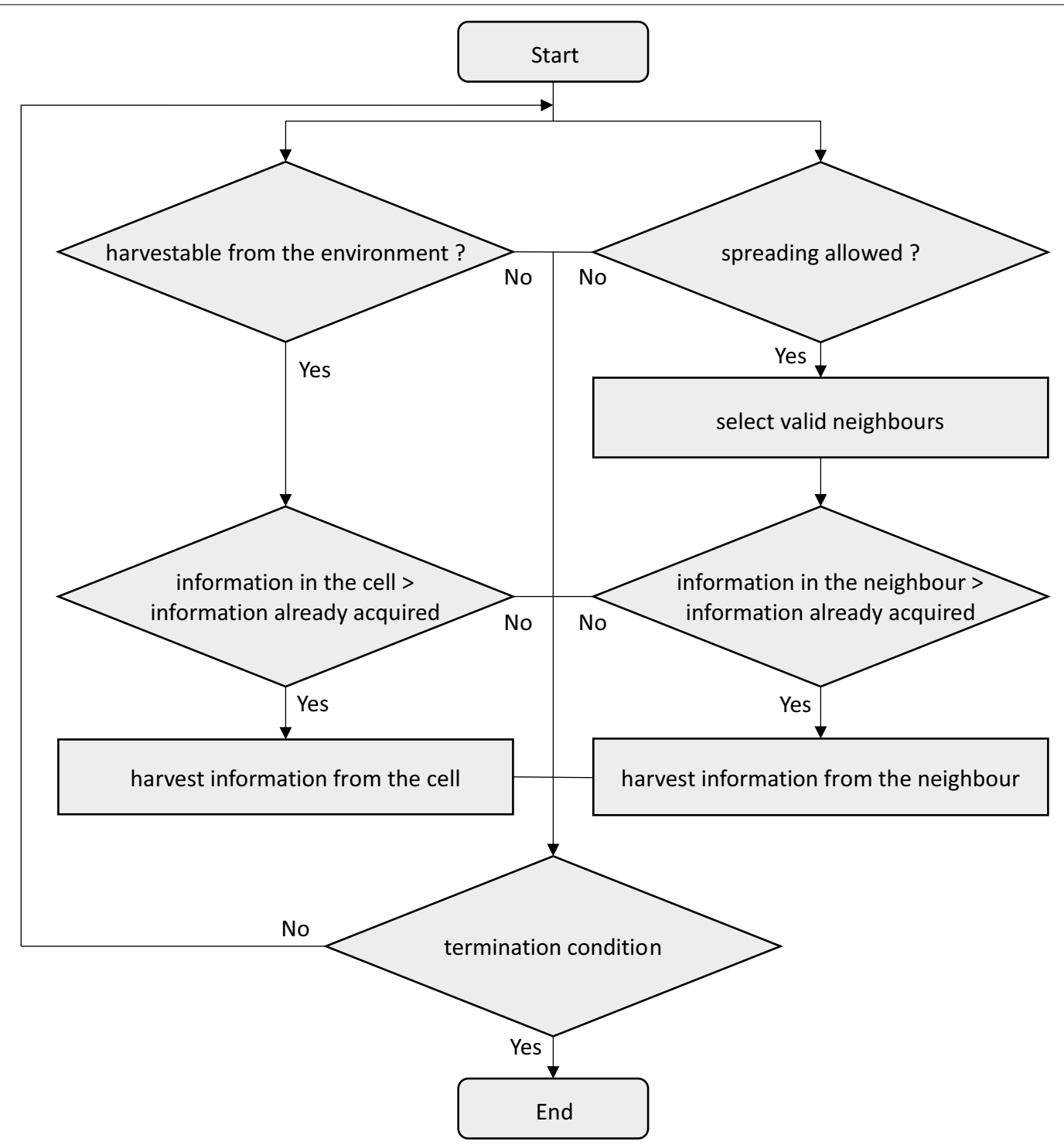

Fig. 2 Flowchart showing the behaviour of the agents for one cycle

$$
I_{i_{j, t+1}}{ }^{\text {agent }}=I_{i_{j, t}}{ }^{\text {agent }}+S_{I_{i, j, t}} .
$$

\section{Cell behaviour}

Similar to information sharing among agents, information spreading from one cell to another neighbouring cell materializes according to Eqs. (9) and (10):

$$
E_{C_{i, j, t}}=\left\{\begin{array}{ll}
\left(C_{i_{i, t}}{ }^{\text {cell }}-C_{i_{j, t}} \text { cell }\right) * C_{i_{N}} ; & C_{i_{i, t}}{ }^{\text {cell }}>C_{i_{j, t}} \text { cell } \\
0 ; & \text { Otherwise }
\end{array},\right.
$$

$$
E_{I_{i, j, t}}= \begin{cases}\left(I_{i_{i, t}}{ }^{\text {cell }}-I_{i_{j, t}}{ }^{\text {cell }}\right) * I_{i_{N}} ; & I_{i_{i, t}}{ }^{\text {cell }}>I_{i_{j, t}}{ }^{\text {cell }} \\ 0 ; & \text { Otherwise }\end{cases}
$$

At each time cycle, if cell level natural spreading is allowed in the environment, each agent's information levels are updated according to Eqs. (11) and (12):

$$
\begin{aligned}
& C_{i_{j, t+1}}{ }^{\text {cell }}=C_{i_{j, t}}{ }^{\text {cell }}+E_{C_{i, j, t}}, \\
& I_{i_{j, t+1}}{ }^{\text {cell }}=I_{i_{j, t}}{ }^{\text {cell }}+E_{I_{i, j, t}} .
\end{aligned}
$$

Any random cell within the visibility range can be selected as the neighbouring cell for information sharing. 
Table 2 Glossary of notations to describe harvesting and spreading of information

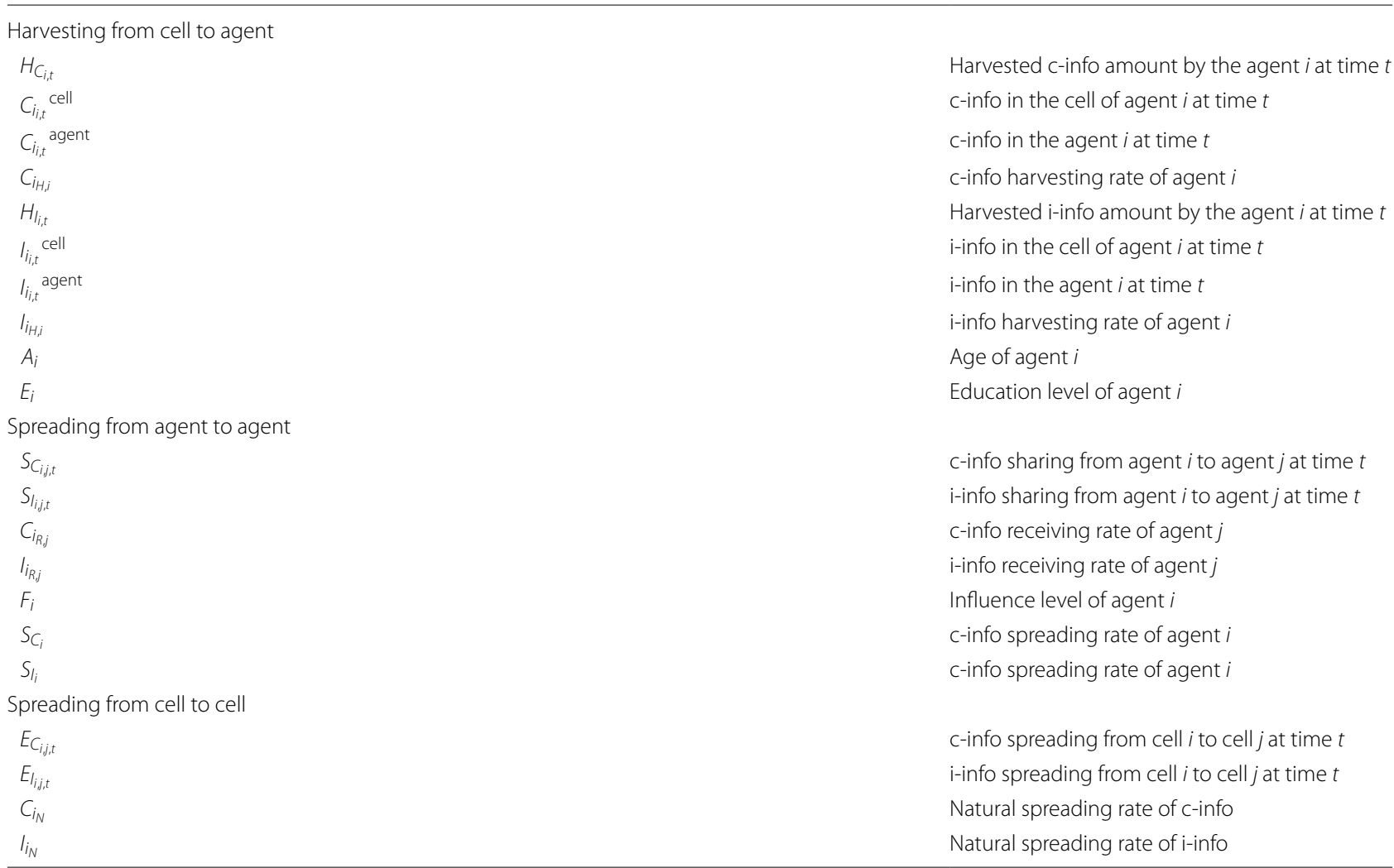

c-info denotes information about collective benefits of tidal energy

i-info denotes information about individual benefits of tidal energy

The overall behaviour of the information flow from cell to cell is captured in Fig. 3.

\section{The ABS model for information flow in Flores Timur Regency}

In this model, the agents are classified into four groups reflecting the generic structures of Flores Timur Regency. As per the hierarchical nature of the local society observed in the field survey [21], information only flows to the agents in the adjacent hierarchy as shown in Table 3 .

Table 3 also highlights the conditions that govern the interaction between agents of different hierarchical groups. Level 1 agents represent the most educated and highly influential locals at the top of the hierarchical structure such as the regency mayor or bishop of the diocese, followed by level 2 agents consisting of high influence locals such as senior regency officers, senior priests, etc. Level 3 and level 4 agents are lower in the hierarchical structure consisting of local people such as fishermen and farmers. In this model, level 1 agents can only share information with other level 1 and level 2 agents, while level 2 agents can share with level 1, level 2, and level 3 agents. Likewise, level 3 agents can share with level 2, level 3, and level 4 agents, but level 4 agents can only share information with level 3 and level 4 agents.

In addition to the demographic factors-age, and education, this ABS uses two types of information for the purposes of simulation: information about collective benefits, and information about individual benefits. Based on the results from the previous study by Ramachandran et al. [21] it is assumed here that these two types of information have the most significant impact in relation to support for tidal energy. Information about collective benefits and information about individual benefits will henceforth be referred to as c-info and i-info, respectively. While input values for age and education can be taken from the statistical model on a scale of one to six, the values for c-info and i-info are represented through harvesting, receiving, and sharing rates in the $\mathrm{ABS}$. While the individual outcome favourability and collective outcome favourability in the statistical model are based on a scale of zero to two, the c-info and i-info harvesting, receiving, and sharing rates in the $\mathrm{ABS}$ are on a scale of $0-1$, with lower values in multinomial probit model corresponding to a lower values ABS and similarly, higher 


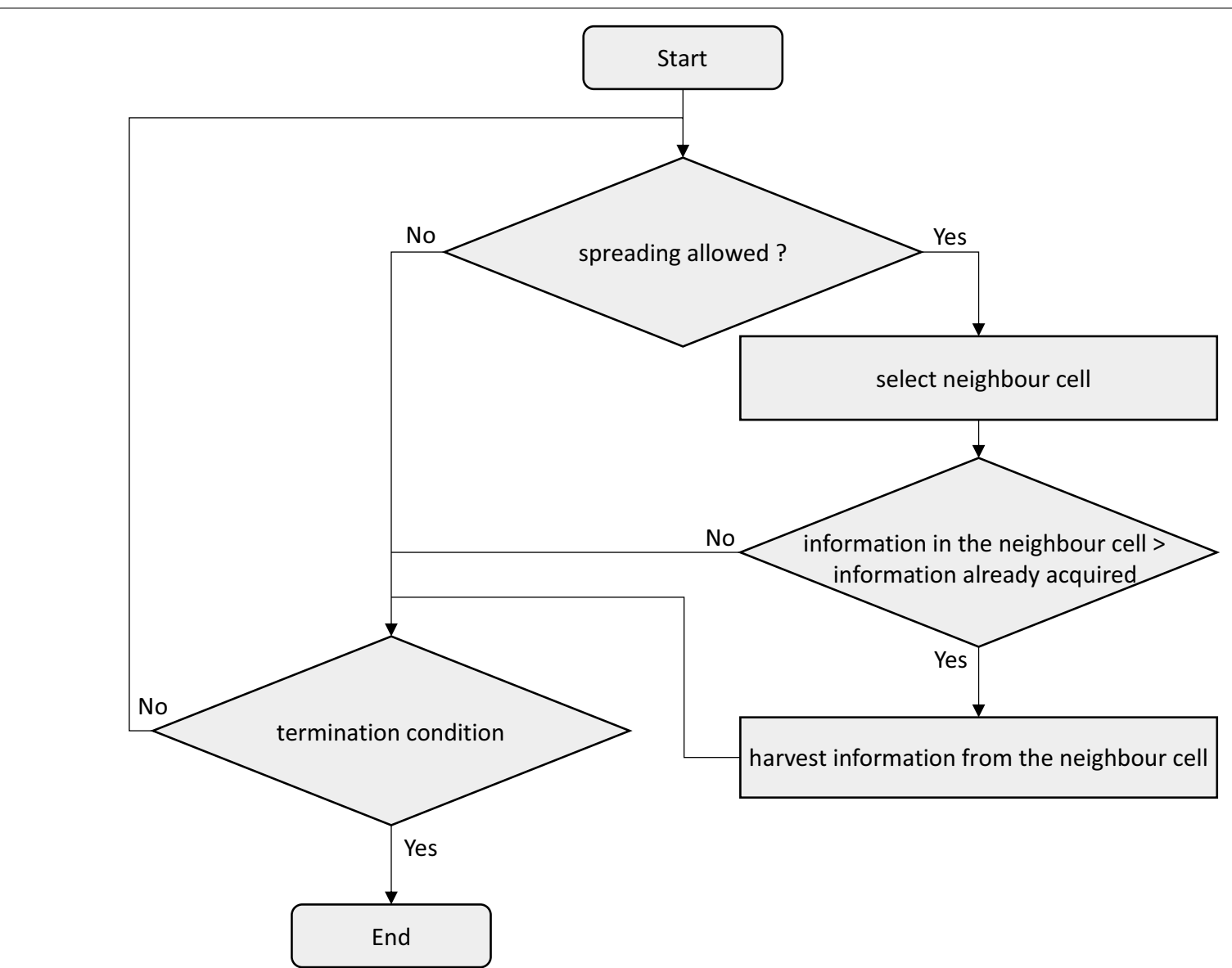

Fig. 3 Flowchart showing information flow between cells for one cycle

Table 3 Characteristics of agents from different hierarchies

\begin{tabular}{lllll}
\hline Agent & Hierarchy & & & \\
\cline { 2 - 5 } & Level 1 & Level 2 & Level 3 & Level 4 \\
\hline Stakeholder type & $\begin{array}{l}\text { Elected officials, senior } \\
\text { regency officials, traditional, } \\
\text { clan leaders, senior priests }\end{array}$ & $\begin{array}{c}\text { Senior district officials, heads } \\
\text { of villages, Business owners, } \\
\text { clergy }\end{array}$ & $\begin{array}{c}\text { Junior village officials, } \\
\text { traditional village elders, } \\
\text { community leaders }\end{array}$ & $\begin{array}{c}\text { Fishermen, farmers, } \\
\text { employees, Other } \\
\text { local residents }\end{array}$ \\
Distribution of agents & $6 \%$ & $14 \%$ & $32 \%$ & $48 \%$ \\
Influence & Very high influence & High influence & Mid influence & Low influence \\
Info sharing & Level 1 & Level 1 & Level 2 & Level 3 \\
With other hierarchical agents & Level 2 & Level 3 & Level 3 & Level 4
\end{tabular}

values in multinomial probit model corresponding to higher values in ABS.

In the ABS, the difference in the hierarchies based on their information preferences are manifest by the information harvesting and information receiving functions. From observations in the field, it is evident that the agents from top hierarchies have higher capability of harvesting information due to their greater access to information, as well as higher education [21]. Likewise, better education also allows agents to receive more information due to higher ability to process more information.

Based on field observation, this model assumes that information flow initiates from the top hierarchical group. Hence, in the initiation of the model, a single level 1 hierarchy member is created in the middle of the simulation environment with $100 \%$ of $\mathrm{i}$-info and c-info 
while all other agents have no information. This model also assumes the location of the agent to be not highly significant, and hence all agents are located randomly such that no two agents are residing in the same cell. Cells are defined such that the centre cell has $100 \%$ of i-info and c-info and all other cells have no information. As the information flows through the environment, and between agents, the simulation calculates the number of information flow cycles it takes for the information to get to the probable agents who support tidal energy.

\section{Model verification and validation}

Before a simulation can be executed, it is important to verify and validate the model [50]. Schlesinger [51] defines verification and validation for the complicated system simulation in the field of operations research $[51,52]$. In general, while verification of the model is defined substantiation that a computerized model represents a conceptual model within specified limits of accuracy, validation of the model is defined substantiation that a computerized model within its domain of applicability possesses a satisfactory range of accuracy consistent with the intended application of the model.

In the phase of verification, debugging which is to inspect the program to detect errors is implemented [53]. In this study, it is implemented by confirming that the simulation model is correctly coded, and the program performs as anticipated from the perspective of findings in the field. One of the key methods employed here for verification is tracing-a form of testing that comprises receiving all intermediate outputs from a computer program automatically, and then comparing it with manually calculated results [54]. To verify that the sharing and harvesting behaviours were working as anticipated, the attribute data for singular patches and agents were inspected, cycle-by-cycle, as the simulation proceeded under specially created test scenarios for which the correct behaviour was already known, and outputs were calculated manually. For these simulation experiments, the intermediate simulation outputs matched the manual calculations, thus supporting the verification of the model.

In the phase of validation, it must be confirmed that the behaviour of the created model and outputs from the model replicate a phenomenon in its actual state. Before any simulation model can be used to replicate a phenomenon in a society, it is important to validate the model for that community to ensure that the model is an accurate representation of the real-world system under study [53]. For this ABS model, primary data on the input parameters was collected using questionnaire survey, expert interviews, and field observations to identify the behaviours exhibited by different groups of individuals in the community [21]. Additionally, secondary sources such as the census data [55], is also employed to define the input parameters for the simulation. Moreover, regression analyses and other statistical measures as described earlier are employed to ensure the viability of the input parameters to replicate the actual situation of the case study area, as well as their use in the ABS. The validation of the simulation model can be accomplished by comparing the simulation outputs with the actual observations from the community.

\section{ABS model simulations \\ ABS base model}

The general design of the model is inspired from the interactions between the members of the local community, and it replicates the ideal characteristics of the actual situation observed in Flores Timur Regency, including the hierarchical nature, age, education, and information preferences [21]. The simulation is arbitrarily set up with 2500 agents classified into four hierarchical groups reflecting the nature of society, with the number of agents in each group distributed according to the values shown in Table 3.

From the interviews with academics, as well as local community leaders, it was clear the society is structured hierarchically with varying influence for each group. Moreover, the education level also changed with the hierarchies, whereby the individuals belonging to the higher hierarchical groups tended to be more educated compared to others. Additionally, the more experienced stakeholders belonged to the higher hierarchical groups. This is reflected in the input parameters where values for age are set at $6,5,3$, and 3 for groups $1,2,3$, and 4, respectively, and values for education are set at $6,4,3$, and 2 for groups 1, 2, 3, and 4, respectively. Based on further interviews and field observations, additional information was collected qualitatively to reflect the local situation in Flores Timur Regency, and is used to set up the remaining parameters for ABS. The harvesting, receiving, and sharing rates for i-info are set 0.05 more than c-info. The harvesting rates for groups $1,2,3$, and 4 , are set at $0.65,0.65,0.45$, and 0.25 , respectively, for c-info and 0.7 , $0.7,0.5$, and 0.3 , respectively, for i-info. The receiving rates for groups $1,2,3$, and 4 , are set at $0.75,0.75,0.55$, and 0.35 , respectively, for c-info and $0.8,0.8,0.6$, and 0.4 , respectively, for i-info. The sharing rate is set at 0.7 for c-info and 0.75 for i-info. The influence of each group also differs by 0.1 with values set at $1.0,0.9,0.8$, and 0.7 for groups 1, 2, 3, and 4. Finally, the information-spread rate between cells is fixed at 0.5 . This study assumes the above parameters and the assigned values reflect the situation in Flores Timur Regency accurately. Description 
of all the parameters used and their given values can be found in Additional file 1: Appendix S1.

The principle idea behind the base model is to replicate the flow of information as observed in a community like Flores Timur, where the information originates from the top level and spreads hierarchically, with the top level acquiring the information at the fastest rate compared to other groups. Additionally, the results of the simulation which enable us to identify strategies can help the project developers in implementing their information provision strategies by testing the impact of making additional information available from the environment, the influence of delayed involvement of agents from some hierarchical levels, and the effect of change in the number of agents in certain hierarchical levels.

GAMA Platform V1.8.0 is used for the simulation.

\section{Additional simulations for parameter study}

To assess the influence of information available from the environment, the information spread rates are set at varied amounts to simulate the spread of information through the environment. The simulation is performed two additional times with information spread rates set at 0.6 and 0.7 , compared to value of 0.5 set for the base model.

To check if there is any significant effect of introducing certain hierarchical groups at varied times in the information flow process, two simulations are performed where level 3 and level 4 agents are introduced after 50 cycles and 70 cycles. Furthermore, two more simulations are executed where only the lowest level 4 agents are introduced in the information flow process after 50 cycles and 70 cycles. All other parameters were kept unaltered compared to the base model.

The impact of the number of agents in any hierarchical group was investigated by performing two additional simulations after altering the number of agents by adding $10 \%$ additional agents and $20 \%$ additional agents to level 2 hierarchy after removing the same number of agents from the lowest level 4 . These simulations were repeated again with $10 \%$ additional agents and $20 \%$ additional agents in level 3, and reducing identical amount of agents from level 4. No other parameters apart from the agent numbers are altered in comparison with the base model.

Table 4 Goodness-of-fit measures

\begin{tabular}{lr}
\hline Log-likelihood & -125.260 \\
LR (log-likelihood ratio) & $250.521^{* * *}$ \\
$R$-square & 0.541 \\
Count & 0.184 \\
Count (adjusted) & \\
\hline
\end{tabular}

*** Indicates $p$-value $<0.01$

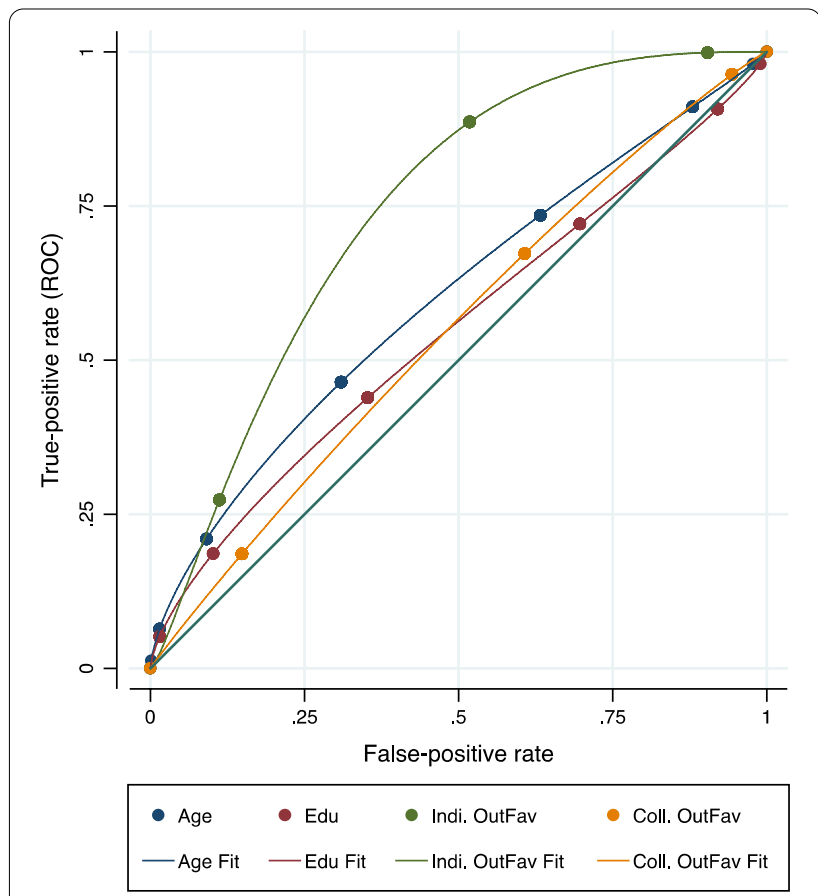

Fig. 4 Receiver operating characteristic (ROC) curve

\section{Results}

Post-estimation measures

The goodness-of-fit measures are presented in Table 4.

As shown in Table 4, the $R$-squared value is in the acceptable range pointing to a good fit of this model.

The ROC curve for the model is shown in Fig. 4.

As Fig. 4 shows, the curves lie above the diagonal line pointing to the higher accuracy of the variables employed.

Table 5 Area under the ROC curve

\begin{tabular}{lccccc}
\hline Variable & Obs & ROC area & Std. Err & \multicolumn{2}{l}{$\begin{array}{l}\text { 95\% conf. } \\
\text { interval }\end{array}$} \\
\cline { 5 - 6 } & & & & $\mathbf{5 \%}$ & $\mathbf{9 5 \%}$ \\
\hline Age & 135 & 0.60 & 0.07 & 0.48 & 0.73 \\
Edu & 135 & 0.54 & 0.07 & 0.42 & 0.67 \\
Indi. OutFav & 135 & 0.72 & 0.05 & 0.62 & 0.81 \\
Coll. OutFav & 135 & 0.55 & 0.06 & 0.43 & 0.67
\end{tabular}

Coll. OutFav indicates the variable "Collective outcome favourability" asked in the field survey. It has three values 0,1 , and 2, respectively, denoting disagree, neither agree nor disagree, and agree

Indi. OutFav indicates the variable "Individual outcome favourability" asked in the field survey. It has three values 0,1 , and 2, respectively, denoting disagree, neither agree nor disagree, and agree

Education, asked in the field survey, is variable with values ranging from 1 to 6 denoting different categories

Age, asked in the field survey, is variable with values ranging from 1 to 6 denoting different categories 
Table 6 Predicted probability of support for tidal energy at specified values for variables using multinomial probit

\begin{tabular}{|c|c|c|c|c|c|c|}
\hline Hierarchy & Coll. OutFav & Indi. OutFav & Education & Age & Prob & \\
\hline \multicolumn{7}{|l|}{ Case 1} \\
\hline Level 1 & 0 & 2 & 6 & 6 & $\begin{array}{l}0.65 \\
(3.36)\end{array}$ & $* * *$ \\
\hline Level 2 & 0 & 2 & 4 & 5 & $\begin{array}{l}0.58 \\
(3.56)\end{array}$ & $* * *$ \\
\hline Level 3 & 0 & 2 & 3 & 3 & $\begin{array}{l}0.38 \\
(2.33)\end{array}$ & $* *$ \\
\hline Level 4 & 0 & 2 & 2 & 3 & $\begin{array}{l}0.32 \\
(1.89)\end{array}$ & $* *$ \\
\hline \multicolumn{7}{|l|}{ Case 2} \\
\hline Level 1 & 0 & 2 & 6 & 6 & $\begin{array}{l}0.65 \\
(3.36)\end{array}$ & $* * *$ \\
\hline Level 2 & 0 & 2 & 4 & 5 & $\begin{array}{l}0.58 \\
(3.56)\end{array}$ & $* * *$ \\
\hline Level 3 & 1 & 2 & 3 & 3 & $\begin{array}{l}0.30 \\
(3.43)\end{array}$ & $* * *$ \\
\hline Level 4 & 1 & 2 & 2 & 3 & $\begin{array}{l}0.26 \\
(2.51)\end{array}$ & $* *$ \\
\hline \multicolumn{7}{|l|}{ Case 3} \\
\hline Level 1 & 1 & 2 & 6 & 6 & $\begin{array}{l}0.57 \\
(3.29)\end{array}$ & $* * *$ \\
\hline Level 2 & 1 & 2 & 4 & 5 & $\begin{array}{l}0.50 \\
(4.57)\end{array}$ & $* * *$ \\
\hline Level 3 & 0 & 2 & 3 & 3 & $\begin{array}{l}0.38 \\
(2.33)\end{array}$ & $* *$ \\
\hline Level 4 & 0 & 2 & 2 & 3 & $\begin{array}{l}0.32 \\
(1.89)\end{array}$ & $* *$ \\
\hline
\end{tabular}

$z$-value is indicated in parentheses with probability

"Level" indicates social hierarchy. For instance, Level 1 denotes the top hierarchical group with level 4 denoting the bottom hierarchical group

Coll. OutFav indicates the variable "Collective outcome favourability" asked in the field survey. It has three values 0 , 1, and 2, respectively, denoting disagree, neither agree nor disagree, and agree

Indi. OutFav indicates the variable "Individual outcome favourability" asked in the field survey. It has three values 0, 1, and 2, respectively, denoting disagree, neither agree nor disagree, and agree

Education, asked in the field survey, is variable with values ranging from 1 to 6 denoting different categories

Age, asked in the field survey, is variable with values ranging from 1 to 6 denoting different categories

*** and ${ }^{* *}$ indicate $p$-value $<0.01$ and 0.05 , respectively

Table 5 shows the area under the curve for the variables in this model.

As described in Table 5, all the variables show ROC area values more than 0.5 pointing to the aptness of the variables.

After ensuring the viability of the four variables, the predicted probability to support tidal energy is estimated based on specific values for the variables. Table 6 shows the values for the four variables and the predicted probability of each hierarchical group to support tidal energy based on those values for the four variables, under all the three cases.

According to the multinomial probit estimations, the people belonging to the top hierarchical group show a probability of $57 \%$ or $65 \%$ to support tidal energy depending on the case. People belonging to the second group show a probability of $50 \%$ or $58 \%$ in support of tidal energy, and the third group shows a probability of $30 \%$ or $38 \%$. Finally, $26 \%$ or $32 \%$ of people from group four will support tidal energy. Table 6 also shows that all the predicted probabilities to support tidal energy are statistically significant.

\section{The base model}

Using the set parameters mentioned earlier for the base model simulation, the resulting graph showing the information growth among various hierarchical agent levels based on information type is shown in Fig. 5.

Results displaying the number of cycles it takes i-info and c-info to flow to the probable number of supporters of tidal energy are shown in Table 7. 


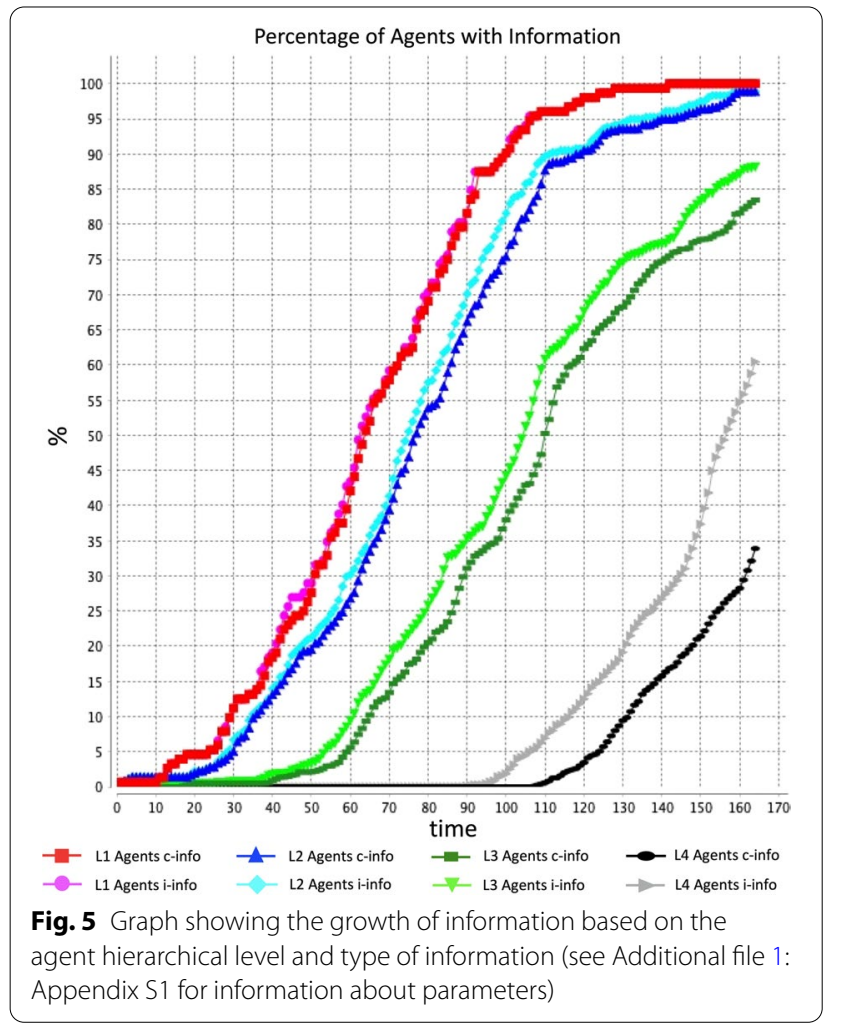

Reflecting the hierarchical nature of the society, the agents from the top hierarchy, i.e. level 1 agents are the fastest to obtain information and agents from the bottom level, level 4 agents are the slowest to acquire information. Under case 1 and case 2, it takes 76 cycles to spread both types of information to probable supporters of tidal energy from top level 1 hierarchical group, however it takes 68 cycles under case 3 . For group 2 agents under case 1 and case 2, it takes 81 cycles to spread i-info and 84 cycles to spread c-info among the probable supporters, while it takes 74 and 76 cycles to spread i-info and c-info, respectively, under case 3. Group 3 supporters who may support tidal energy take 94,83 , and 94 cycles to obtain i-info under cases 1,2, and 3, respectively, and 99, 89, and 99 cycles to absorb c-info under respective cases 1,2 , and 3. Level 4 agents require 146 and 162 cycles for i-info and c-info flows under case 1, 138 and 155 cycles for i-info and c-info flows under case 2, and 146 and 162 cycles for i-info and c-info flows under case 3 to achieve the probable support for tidal energy.

Table 7 also shows case 3 is the fastest scenario for information flow to agents belonging to top hierarchical groups 1 and 2, and case 2 is the fastest scenario for agents belonging to the bottom hierarchical groups 3 and 4 . Most importantly, case 1 can be characterized
Table 7 Number of cycles to disseminate information to probable supporters of tidal energy

\begin{tabular}{|c|c|c|c|}
\hline Hierarchy & Prob & Info type & $\begin{array}{l}\text { Number } \\
\text { of cycles }\end{array}$ \\
\hline \multicolumn{4}{|l|}{ Case 1} \\
\hline \multirow[t]{2}{*}{ Level 1} & 0.65 & i-info & 76 \\
\hline & & c-info & 76 \\
\hline \multirow[t]{2}{*}{ Level 2} & 0.58 & i-info & 81 \\
\hline & & c-info & 84 \\
\hline \multirow[t]{2}{*}{ Level 3} & 0.38 & i-info & 94 \\
\hline & & c-info & 99 \\
\hline \multirow[t]{2}{*}{ Level 4} & 0.32 & i-info & 146 \\
\hline & & c-info & 162 \\
\hline \multicolumn{4}{|l|}{ Case 2} \\
\hline \multirow[t]{2}{*}{ Level 1} & 0.65 & i-info & 76 \\
\hline & & c-info & 76 \\
\hline \multirow[t]{2}{*}{ Level 2} & 0.58 & i-info & 81 \\
\hline & & c-info & 84 \\
\hline \multirow[t]{2}{*}{ Level 3} & 0.30 & i-info & 83 \\
\hline & & c-info & 89 \\
\hline \multirow[t]{2}{*}{ Level 4} & 0.26 & i-info & 138 \\
\hline & & c-info & 155 \\
\hline \multicolumn{4}{|l|}{ Case 3} \\
\hline \multirow[t]{2}{*}{ Level 1} & 0.57 & i-info & 68 \\
\hline & & c-info & 68 \\
\hline \multirow[t]{2}{*}{ Level 2} & 0.50 & i-info & 74 \\
\hline & & c-info & 76 \\
\hline \multirow[t]{2}{*}{ Level 3} & 0.38 & i-info & 94 \\
\hline & & c-info & 99 \\
\hline \multirow[t]{2}{*}{ Level 4} & 0.32 & i-info & 146 \\
\hline & & c-info & 162 \\
\hline
\end{tabular}

i-info denotes information about individual benefits of tidal energy

c-info denotes information about collective benefits of tidal energy

Final column indicates the no. of cycles it takes for information to reach the probable number of supporters with the probability indicated in second column

as the standard scenario for information flow among all hierarchical groups.

\section{Influence of information spread rate}

To identify the best pathways for information provision, certain parameters are altered compared to the base model. Results from all approaches to the simulation, showing the information growth of c-info and i-info for all agents are summarized in Fig. 6.

Table 8 shows the number of cycles it takes for information to flow to probable supporters of tidal energy in each hierarchical group under varied simulation conditions.

When the amount of information available in the environment is altered by increasing the information spread rate, the amount of information acquired by the agents changes significantly. Graphs 1 and 2 in Fig. 6 show 


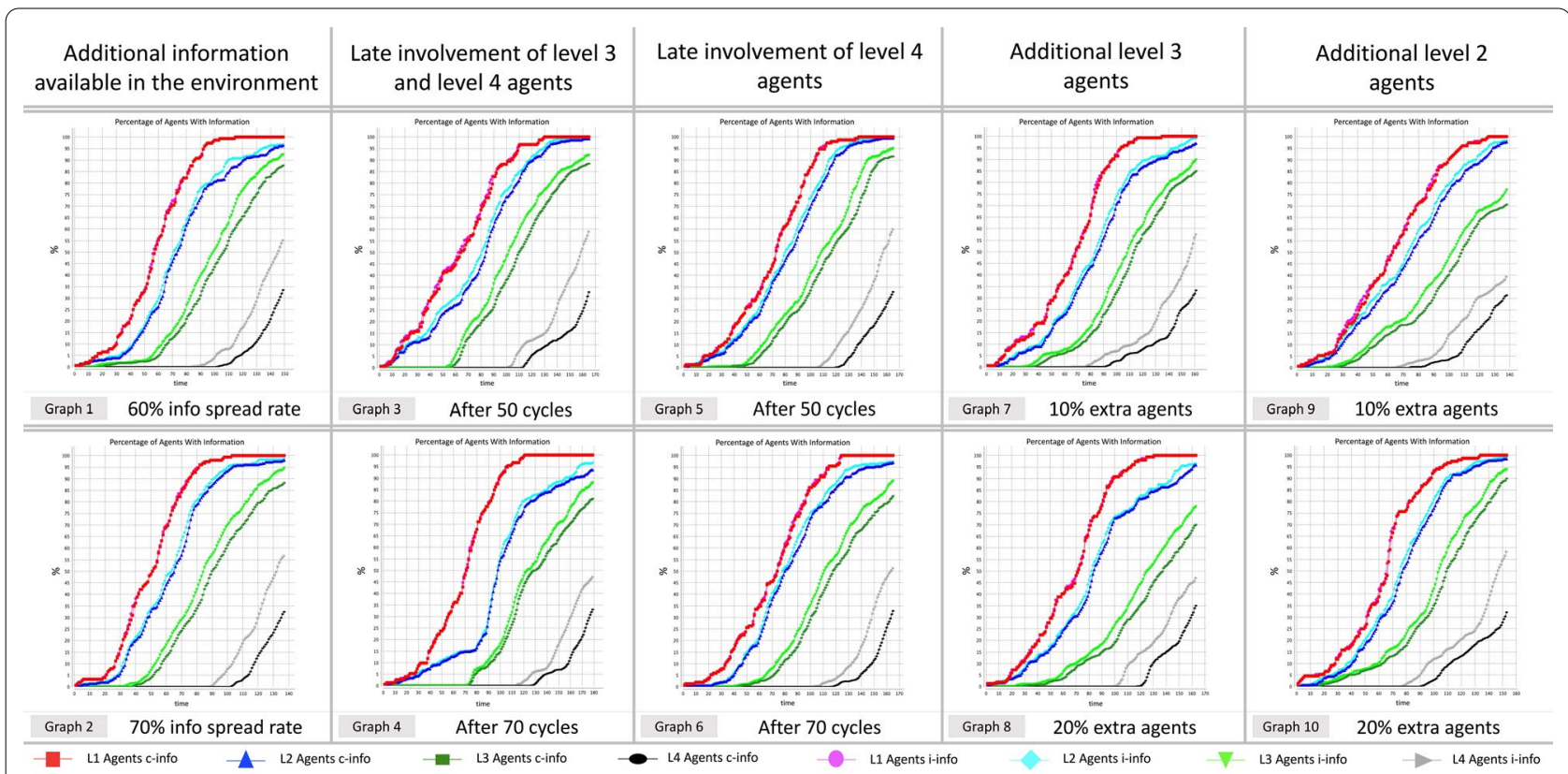

Fig. 6 Graphs of various simulation approaches showing i-info and c-info acquired for each hierarchical group (see Additional file 1: Appendix S1 for information about parameters)

the amount of information possessed by various agent groups when information spread rate in the environment is at $60 \%$ and $70 \%$, respectively, compared to the base model where the information spread rate is at $50 \%$. Table 8 shows that information flow to the probable supporters of tidal energy is much faster when there is more information available in the environment for all the hierarchical groups in all the three cases.

In the instance of graph 1 , characterized by $60 \%$ information spread rate, i-info takes on average 8 cycles less than the base model to spread to the probable supporters of tidal energy in all the hierarchical groups for the first case. Similarly, i-info, on average, takes six cycles less for the second case and eight cycles less for the third case to spread to all groups. Likewise, c-info takes on average 8, 7 , and 7 cycles less than the base model for case 1 , case 2 , and case 3 , respectively.

When the information spread rate is at $70 \%$ as exemplified in graph 2, information flow process becomes significantly faster. It takes i-info, on average, 19, 16, and 17 fewer cycles than the base model for case 1 , case 2 , and case 3, respectively, to flow to the probable supporters of tidal energy in all hierarchical groups. Likewise, c-info takes 19, 17, and 17 cycles less than the base model on average for case 1 , case 2 , and case 3 , respectively.

\section{Later involvement of lower hierarchical level agents}

Graphs 3 and 4 in Fig. 6 show the information growth when agents from lower hierarchical levels, groups 3 and 4, get involved in the information flow process only after 50 cycles and 70 cycles, respectively. According to the results shown in Table 8, the information flows 6-8 cycles slower for graph 3 and 13-16 cycles slower for graph 4 compared to the base model, on average for all the groups under all the case parameters.

Graphs 5 and 6 in Fig. 6 show the information growth when agents from the bottom hierarchical level group 4, get involved in the information flow process only after 50 cycles and 70 cycles, respectively. Table 8 shows that the information flows $4-6$ cycles slower for graph 5 and 5-7 cycles slower for graph 6 compared to the base model, on average for all the groups under all the case parameters.

\section{Different level-wise distribution of agents}

Graphs 7 and 8 in Fig. 6 show the information growth when the number of agents is increased in level 3 with the equal number of agents reduced in level 4 . When the proportion of agents from level 3 is increased by $10 \%$, the information flow takes 2-4 cycles compared to the base model longer to get to all the agent groups under all the cases as shown by graph 7 in Table 8 . Similarly, when there are $20 \%$ additional level 3 agents, the information flow is prolonged by a further $5-8$ cycles for all the hierarchical groups as shown by graph 8 in Table 8 .

Graphs 9 and 10 in Fig. 6 show the information growth when the number of agents is increased in level 2 with the equal number of agents reduced in level 4 . When the proportion of agents from level 2 is increased by $10 \%$, the 


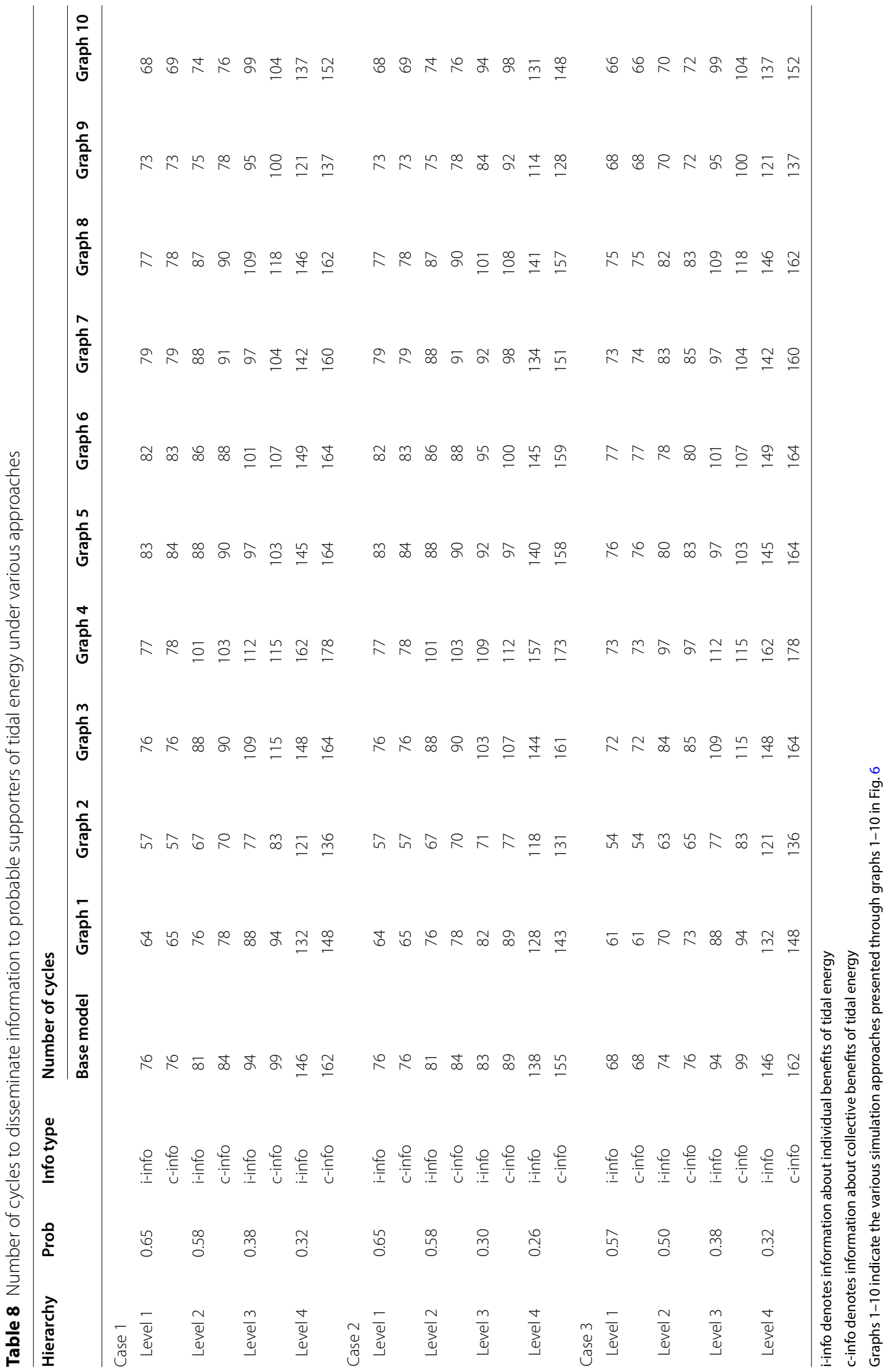


information flow becomes faster by 7-8 cycles compared to the base model as shown by graph 9 in Table 8 . Similarly, when there are $20 \%$ additional level 2 agents, the information flow is shortened by $2-5$ cycles for all the hierarchical groups as shown by graph 10 in Table 8 .

\section{Discussion}

\section{Efficient information dissemination}

In areas such as diffusion of an innovation, or spread of panic or riots, transmission of diseases, or public health advisories, the study of how information is generated, and the dynamics affecting how it is disseminated, has a prominent position in the field of social sciences. However, few studies have explored information dissemination strategies for increasing support of renewable energy technologies. In this context, this study highlights vital strategies that can lead to increase in support for tidal energy by identifying the key factors that affect the flow of information in a local community.

Information dissemination activities can be more efficient when the type of information that is more effective locally is diffused in the community. As the results from the post-estimation ROC curve indicate, individual outcome favourability is the most significant variable in driving support for tidal energy. Accordingly, as ABS shows i-info spreads faster through all hierarchical groups compared to c-info, the developers should focus more on disseminating information that focuses on benefits of tidal energy that specifically cater to the individual, as opposed to the information that concentrates on community benefits. For example, the developers should focus more on disseminating information related to additional jobs that benefit individuals, compared to the information about infrastructure development, which supports the whole community.

\section{Short-term strategies}

When the information available from the environment is very low, the agent information levels are similarly at low level. However, when there is additional information is available to be absorbed by the agents, even the agents belonging to low hierarchy are able to gain information. Figure 7a shows the information growth for all hierarchical groups when the cell-to-cell information spread rate is at $90 \%$ resulting in abundance of information available in the environment. Table $9 \mathrm{a}$ shows the number of cycles needed to spread information to the probable supporters of tidal energy. With additional information available, information takes 25-29 cycles less on average compared

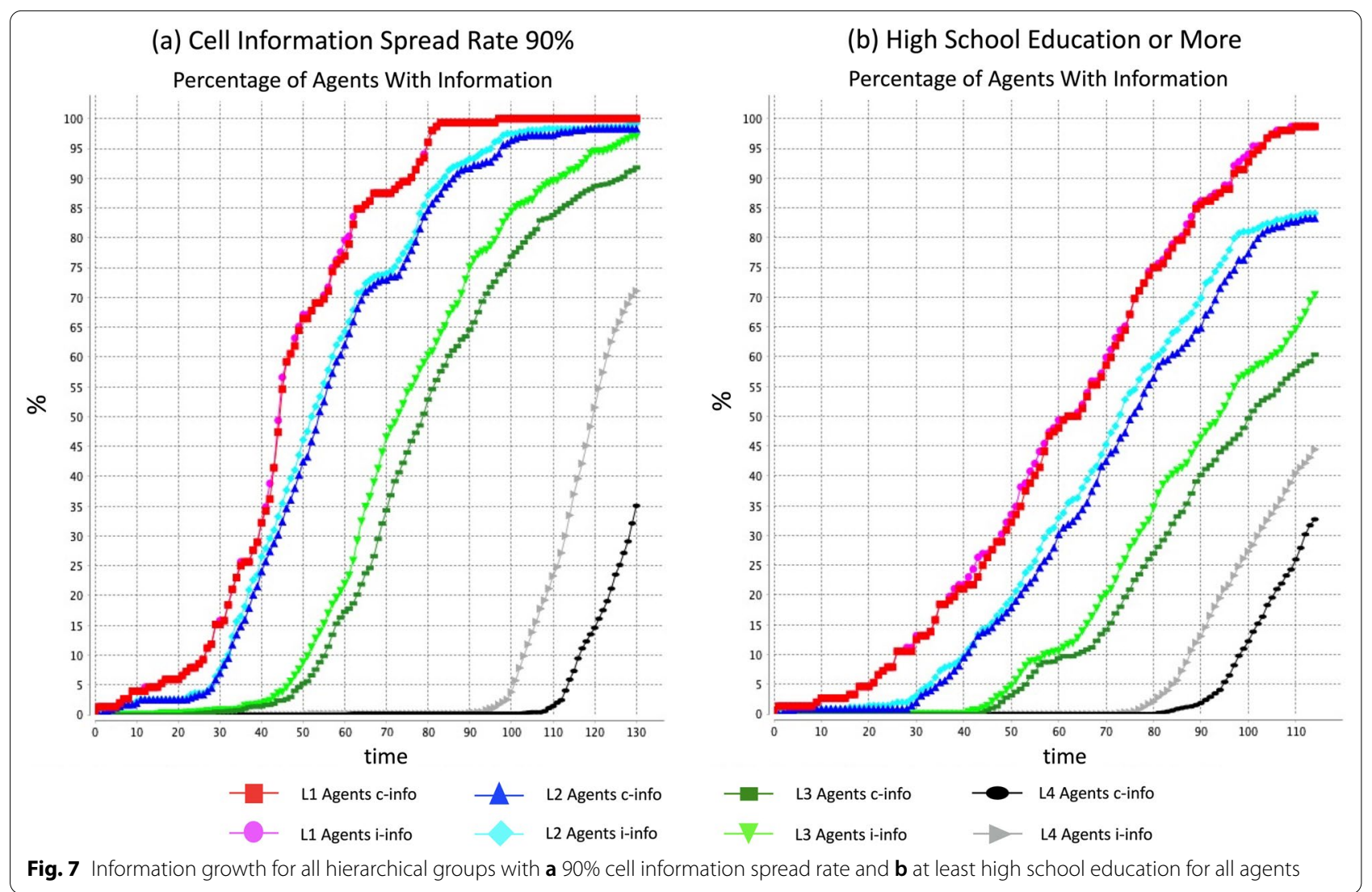


Table 9 Number of cycles to spread information to probable supporters of tidal energy with (a) high information availability due to $90 \%$ information spread rate and (b) higher education values when every agent has at least high school education

\begin{tabular}{|c|c|c|c|c|c|}
\hline \multirow[t]{2}{*}{ Hierarchy } & \multirow[t]{2}{*}{ Prob } & \multirow[t]{2}{*}{ Info type } & \multicolumn{3}{|c|}{ Number of cycles } \\
\hline & & & Base model & $\begin{array}{l}\text { (a) } 90 \% \text { cell info spread } \\
\text { rate }\end{array}$ & $\begin{array}{l}\text { (b) High school } \\
\text { education or } \\
\text { more }\end{array}$ \\
\hline \multicolumn{6}{|l|}{ Case 1} \\
\hline \multirow[t]{2}{*}{ Level 1} & 0.65 & i-info & 76 & 48 & 73 \\
\hline & & c-info & 76 & 49 & 74 \\
\hline \multirow[t]{2}{*}{ Level 2} & 0.58 & i-info & 81 & 56 & 78 \\
\hline & & c-info & 84 & 57 & 80 \\
\hline \multirow[t]{2}{*}{ Level 3} & 0.38 & i-info & 94 & 66 & 81 \\
\hline & & c-info & 99 & 71 & 88 \\
\hline \multirow[t]{2}{*}{ Level 4} & 0.32 & i-info & 146 & 112 & 103 \\
\hline & & c-info & 162 & 129 & 113 \\
\hline \multicolumn{6}{|l|}{ Case 2} \\
\hline \multirow[t]{2}{*}{ Level 1} & 0.65 & i-info & 76 & 48 & 73 \\
\hline & & c-info & 76 & 49 & 74 \\
\hline \multirow[t]{2}{*}{ Level 2} & 0.58 & i-info & 81 & 56 & 78 \\
\hline & & c-info & 84 & 57 & 80 \\
\hline \multirow[t]{2}{*}{ Level 3} & 0.30 & i-info & 83 & 63 & 77 \\
\hline & & c-info & 89 & 68 & 83 \\
\hline \multirow[t]{2}{*}{ Level 4} & 0.26 & i-info & 138 & 111 & 98 \\
\hline & & c-info & 155 & 126 & 109 \\
\hline \multicolumn{6}{|l|}{ Case 3} \\
\hline \multirow[t]{2}{*}{ Level 1} & 0.57 & i-info & 68 & 45 & 68 \\
\hline & & c-info & 68 & 45 & 69 \\
\hline \multirow[t]{2}{*}{ Level 2} & 0.50 & i-info & 74 & 52 & 72 \\
\hline & & c-info & 76 & 53 & 75 \\
\hline \multirow[t]{2}{*}{ Level 3} & 0.38 & i-info & 94 & 66 & 81 \\
\hline & & c-info & 99 & 71 & 88 \\
\hline \multirow[t]{2}{*}{ Level 4} & 0.32 & i-info & 146 & 112 & 103 \\
\hline & & c-info & 162 & 129 & 113 \\
\hline
\end{tabular}

i-info denotes information about individual benefits of tidal energy

c-info denotes information about collective benefits of tidal energy

to the base model to be absorbed by probable supporters of tidal energy.

The developers should focus on getting as much information as possible available to the public by not only relying on mouth-to-mouth communication, but also by employing traditional promotional methods such as newspaper and television advertisements, or employing more modern approaches such as promotions through social media applications that are becoming increasingly popular in Flores Timur. Additionally, during discussions with the local government officers as well as members of the general public, it emerged that the locals currently the locals use the television most frequently for acquiring information, and so the developers should consider using local television as a method to provide additional information to the public to achieve maximum impact.
Developers should also take full advantage of current local practices of information delivery through community consultation workshops known as 'socialization' events in Flores Timur Regency. Developers can strategize on how they conduct their socialization sessions or who to focus their advertisements on. The results also show that there is low impact on the information flow when the lower hierarchy agents are introduced in the information flow only at later stages. In practice, the developers can design their promotional activities separately for the higher hierarchical groups, who can be targeted earlier, compared to the lower hierarchical groups who make up the bulk of the population and can be included later. For instance, the developers can hold the socialization sessions with only the most influential local stakeholders in the initial stages, thereby make savings 
in terms of cost, time, and effort that may otherwise be spent on mass promotional activities.

This strategy is not only significant to realize the savings, but also extremely important if one considers the current practices in Indonesia where the local population looks to the influential figures known as tokoh masyarakat', such as prominent politicians or religious leaders, for advice on all matters of public importance. In recent years, 'tokoh masyarakat' have been effective in informing the public on the ways to fight against the Covid-19 pandemic using their knowledge and attitudes [56]. In a similar manner, 'tokoh masyarakat' can be provided with complex information such as scientific data from environmental agencies or fishery departments highlighting the benefits to the farmers and fishermen. They can then use their knowledge, influence, and leadership to disseminate the information in a simplified way that everyone can understand, and hence educate the society as well as increase the support for tidal energy.

\section{Long-term strategies}

Additionally, the developers can also focus on long-term plans that go beyond increasing information provision for a few cycles. The effectiveness of the information flow is highest when the community is well educated, and adds on to the point made by the head of the non-formal education in Flores Timur who emphasized the role of education in the development of Flores Timur Regency. In Flores Timur only $11.38 \%$ of the population have a high school diploma, with only $3.31 \%$ having college level education. Strikingly however, $32.15 \%$ of those aged over 10 years, have not graduated from any institution providing formal education [55]. Figure $7 \mathrm{~b}$ shows the information growth for all hierarchical groups when all the agents possess high school education or more. Table $9 \mathrm{~b}$ shows the number of cycles to spread information efficiently to the probable supporters of tidal energy when all the agents have at least high school level education. As displayed in Table 9b, information takes 13-16 cycles less on average to be absorbed by probable supporters of tidal energy. While this is an ideal scenario and may take many years to implement successfully, it shows excellent results in making information flow faster and more efficient, especially for the masses belonging to the lowest hierarchical group 4 who take $40-49$ cycles less on average under all the three cases.

While the government and policy makers focus on improving the current infrastructure for formal school education, the developers can also get further involved in the community by focusing their CSR efforts on community educational activities. Project developers can team up with NGOs and community organizations to promote adult education programmes in the society as has been practised in other areas, thereby directly contributing to increasing literacy rate of the local society, while indirectly benefitting with the higher levels of support for their project [57-60]. This observation further validates the opinion made in an interview by the head of the non-formal education in Flores Timur who emphasized the role of education in the overall development of Flores Timur Regency. In this way the project developers not only directly contribute on attaining SDG 7, but also make efforts toward realizing SDG 4: Education [61].

\section{Conclusions and limitations \\ Conclusion}

The purpose of this study is to identify the most efficient strategies for information provision to promote tidal energy in a remote isolated area of a developing country through simulation of agent-based simulation (ABS) model built with the estimation results of Multinomial probit model which is extended from Ramachandran et al. [21]. The notable feature of this paper is combining the simulation by the scenario from field observation with validated estimation results of multinominal probit model for questionnaire survey to reflect the actual status of case area, which is Flores Timur Regency, Indonesia. After validating the results of multinominal probit model by post-estimation, factors for the ABS are defined from field observation: social hierarchy, and information types which are i-info (information about individual benefits) and c-info (information about collective benefits).

The ability of the created model to capture real-world pattern of information flow in Flores Timur Regency indicates that the findings may have significant insights contributing to successful deployment of tidal energy in Indonesia. Information pertaining to the individual benefits of tidal energy deployment in Flores Timur is most effective when pursuing public engagement strategies based on information provision as proven by results from the multinomial probit modelling. Information provision strategies are highly effective when there is additional information available to be absorbed by the local population as graphs 1 and 2 in Table 8 show that information flows fastest to all hierarchical groups when the information-spreading rate is increased.

Additionally, specific implications can also be derived from the results of the study. The developers can strategize information provision by focusing on the most influential stakeholders initially, before including all other locals, thereby saving cost, time, and effort-a strategy based on results displayed in graphs 3 to 6 in Table 8 which show the minimal impact of late involvement of certain hierarchical groups in information flow process. Finally, the most effective strategy, though long-term, involves having highly educated local population, which 
can aid the developers in making inroads with the local community by engaging in education programmes resulting in multiple mutual benefits.

This study based on agent-based simulation not only addresses the lack of studies for tidal energy in developing countries, but it does so from the perspective of project developers, while proposing pathways for information provision strategies necessary to sustainably deploy tidal energy projects. Additionally, the short, medium, and long-term strategies outlined in this study contribute toward achievement of multiple SDGs.

\section{Limitations}

Expectedly, the model is a simplification of the real-world system, with several improvements that can be considered for future research. First, this simulation focuses on mouth-to-mouth information flow between the agents and the impact of increasing availability of communication technologies has not been captured. Arguably, the use of modern social media communication applications may have a significant impact on the flow of information, which is not specifically addressed in the model. Second, this model assumes the initial information level to be equal for all the agents, while in practical terms, the initial information about tidal energy may differ from person to person. Third, this study only considers two types of information-c-info and i-info-that can increase support for tidal energy as revealed by Ramachandran et al. [21], however, in some cases, new information such as impact on marine life or the visible infrastructure, can potentially reduce support for marine energy [19]. Fourth, this model assigns the location in the environment on a random basis, though it may be possible that agents belonging to various hierarchical groups might be found together in clusters. Finally, this model assumes a constant rate of information dissemination through all the cycles. Studies show the rate of information diffusion to be high when the process of dissemination begins, but it gradually tends to dwindle down to lower rates. Moreover, as information disseminates from person to person, the natural trend is an erosion of the initial information [62].

\section{Abbreviations}

SDG: Sustainable Development Goal; ABS: Agent-based simulation; ROC: Receiving operating characteristic.

\section{Supplementary Information}

The online version contains supplementary material available at https://doi. org/10.1186/s13705-021-00302-8.

Additional file 1: Appendix S1. Simulation input parameters.

\section{Acknowledgements}

The authors thank AJE for their assistance in editing.

\section{Authors' contributions}

RR performed literature analysis, data collection, and multinomial probit analysis for the case of Flores Timur Regency with a focus on the local social hierarchical structures and information preferences. He also defined the agent-based simulation model parameters and functions. SK created the programming code for the agent-based simulation model using GAMA platform, including its testing and validation procedures. HM was a major contributor in the design of the study and the manuscript. KT supported and supervised these activities. All the authors contributed and checked the paper. All authors read and approved the final manuscript.

Funding

Not applicable.

Availability of data and materials

All data generated or analysed during this study are available from the corresponding author on reasonable request.

\section{Declarations}

Ethics approval and consent to participate

Not applicable.

Consent for publication

Not applicable.

\section{Competing interests}

The authors declare that they have no competing interests.

\section{Author details}

${ }^{1}$ Graduate Program in Sustainability Science-Global Leadership Initiative (GPSS-GLI), Graduate School of Frontier Sciences, The University of Tokyo, Room 334, Building of Environmental Studies, 5-1-5 Kashiwanoha, Kashiwa, Chiba 277-8563, Japan. ${ }^{2}$ Department of Agricultural Innovation for Sustainable Society, Faculty of Agriculture, Tokyo University of Agriculture, Tokyo, Japan. ${ }^{3}$ Department of Ocean Technology, Policy, and Environment, Graduate School of Frontier Sciences, The University of Tokyo, Kashiwa, Chiba, Japan.

Received: 22 February 2021 Accepted: 9 July 2021

Published online: 21 July 2021

References

1. Masson-Delmotte V, Zhai P, Pörtner H-O, et al (2018) Global Warming of $1.5^{\circ} \mathrm{C}$. An IPCC special report on the impacts of global warming of $1.5^{\circ} \mathrm{C}$ above pre-industrial levels and related global greenhouse gas emission pathways, in the context of strengthening the global response to the threat of climate change. Geneva

2. IEA, IRENA, UNSD, et al (2020) Tracking SDG 7: the energy progress report. Washington, DC

3. Polagye B, Van Cleve B, Copping A, Kirkendall K (2010) Environmental effects of tidal energy development. Washington, DC

4. Sakata K, Gonoji T, Takagi K (2012) A motion of twin type ocean current turbines in realistic situations. In: 2012 Oceans-Yeosu, pp 1-9

5. OES (2019) OES Annual report 2019. Lisbon

6. VanZwieten J, Driscoll FR, Leonessa A, Deane G (2006) Design of a prototype ocean current turbine-Part I: mathematical modeling and dynamics simulation. Ocean Eng 33:1485-1521. https://doi.org/10.1016/j.ocean eng.2005.10.005

7. VanZwieten J, Driscoll FR, Leonessa A, Deane G (2006) Design of a prototype ocean current turbine-Part II: flight control system. Ocean Eng 33:1522-1551. https://doi.org/10.1016/j.oceaneng.2005.10.006

8. Takagi K, Waseda T, Nagaya S, et al (2012) Development of a floating current turbine. In: 2012 Oceans-Hampton Roads, VA, pp 1-5 
9. Gonoji T, Takagi K (2014) Motion of a Twin-Rotor Ocean current turbine in Transient State. J Japan Soc Nav Archit Ocean Eng 20:157-164. https:// doi.org/10.2534/jjasnaoe.20.157

10. Lande-Sudall D, Stallard T, Stansby P (2019) Co-located deployment of offshore wind turbines with tidal stream turbine arrays for improved cost of electricity generation. Renew Sustain Energy Rev 104:492-503. https:// doi.org/10.1016/j.rser.2019.01.035

11. Melorose J, Perroy R, Careas S (2015) MeyGen tidal energy project-non technical summary. MeyGen Environ Summ Non Tech Rep. https://doi. org/10.1017/CBO9781107415324.004

12. Allan G, Gilmartin M, McGregor P, Swales K (2011) Levelised costs of Wave and Tidal energy in the UK: cost competitiveness and the importance of "banded" renewables obligation certificates. Energy Policy 39:23-39. https://doi.org/10.1016/j.enpol.2010.08.029

13. Allan GJ, Lecca P, McGregor PG, Swales JK (2014) The economic impacts of marine energy developments: a case study from Scotland. Mar Policy 43:122-131. https://doi.org/10.1016/j.marpol.2013.05.003

14. Stallard T (2012) Economics of ocean energy. In: Sayigh A (ed) Comprehensive renewable energy. Elsevier Ltd, Oxford, pp 151-169

15. Uihlein A, Magagna D (2016) Wave and tidal current energy — a review of the current state of research beyond technology. Renew Sustain Energy Rev 58:1070-1081. https://doi.org/10.1016/j.rser.2015.12.284

16. Kerr S, Watts L, Colton J et al (2014) Establishing an agenda for social studies research in marine renewable energy. Energy Policy 67:694-702. https://doi.org/10.1016/j.enpol.2013.11.063

17. Edenhofer O, Madruga RP, Sokona Y et al (2011) Renewable energy sources and climate change mitigation: special report of the intergovernmental panel on climate change. Cambridge University Press, Cambridge

18. Aitken M (2014) E-planning and public participation. Int J E-Plan Res 3:38-53. https://doi.org/10.4018/ijepr.2014040103

19. Firestone J, Kempton W (2007) Public opinion about large offshore wind power: underlying factors. Energy Policy 35:1584-1598. https://doi.org/ 10.1016/j.enpol.2006.04.010

20. Biamah EK, Kiio J, Kogo B (2013) Environmental impact assessment in Kenya. In: Developments in earth surface processes. Elsevier BV, pp 237-264

21. Ramachandran R, Takagi K, Matsuda H (2020) Enhancing local support for tidal energy projects in developing countries: case study in Flores Timur Regency, Indonesia. Bus Strateg Dev. https://doi.org/10.1002/bsd2.120

22. Singh V, Verma P, Muthukumaar V et al (2020) Immunization strategy for epidemic spreading based on membership $(\mathrm{m})$ over a multilayer network. Bus Strateg Dev 3:185-194. https://doi.org/10.1002/bsd2.87

23. Kularathna AHTS, Suda S, Takagi K, Tabeta S (2019) Evaluation of coexistence options of marine renewable energy projects in Japan. Sustainability 11:2840. https://doi.org/10.3390/su11102840

24. Blunden LS, Bahaj AS, Aziz NS (2013) Tidal current power for Indonesia? An initial resource estimation for the Alas Strait. Renew Energy 49:137-142. https://doi.org/10.1016/j.renene.2012.01.046

25. Reve (2019) Indonesia has the potential to generate 788,000 megawatts (MW) of power from renewable energy sources such as wind power, solar, tidal, and geothermal | REVE News of the wind sector in Spain and in the world. https://www.evwind.es/2019/08/19/indonesia-has-thepotential-to-generate-788000-megawatts-mw-of-power-from-renew able-energy-sources-such-as-wind-power-solar-tidal-and-geothermal/ 68501. Accessed 30 May 2020

26. Ajiwibowo H, Lodiwa KS, Pratama MB, Wurjanto A (2017) Field measurement and numerical modeling of tidal current in larantuka strait for renewable energy utilization. Int J GEOMATE 13:124-131. https://doi.org/ 10.21660/2017.39.98548

27. Orhan K, Mayerle R, Narayanan R, Pandoe W (2016) Investigation of the energy potential from tidal stream currents in Indonesia. Coast Eng Proc Manage. https://doi.org/10.9753/icce.v35.management.10

28. Orhan K, Mayerle R, Widodo W (2015) Assessment of energy production potential from tidal stream currents in Indonesia. Energy Procedia 76:7-16. https://doi.org/10.1016/j.egypro.2015.07.834

29. Orhan K, Mayerle R (2017) Assessment of the tidal stream power potential and impacts of tidal current turbines in the Strait of Larantuka, Indonesia. Energy Procedia 125:230-239. https://doi.org/10.1016/j.egypro.2017.08. 199
30. Orhan K, Mayerle R (2020) Potential hydrodynamic impacts and performances of commercial-scale turbine arrays in the strait of Larantuka, Indonesia. J Mar Sci Eng 8:223. https://doi.org/10.3390/jmse8030223

31. Erwandi, Afian K, Sasoko P, et al (2011) Vertical axis marine current turbine development in indonesian hydrodynamic laboratory-surabaya for tidal power plant. In: International conference and exhibition on sustainable energy and advanced materials (ICE SEAM 2011). Solo, Indonesia, pp $15-23$

32. Masduki AYdA (2011) Potential energy of ocean current for electric power generation in coastal areas of East Flores, NTT. J IImu dan Teknol Kelaut Trop 3:13-25

33. Firdaus AM, Houlsby GT, Adcock TAA (2020) Tidal energy resource in Larantuka Strait, Indonesia. Proc Inst Civ Eng - Energy 173:81-92. https:// doi.org/10.1680/jener.19.00042

34. Weeks M (1997) The multinomial probit model revisited: a discussion of parameter estimability, identification and specification testing. J Econ Surv 11:297-320. https://doi.org/10.1111/1467-6419.00035

35. Sheffi Y, Hall R, Daganzo C (1982) On the estimation of the multinomial probit model. Transp Res Part A Gen 16:447-456. https://doi.org/10.1016/ 0191-2607(82)90071-1

36. Trivedi PK, Cameron AC (2010) Microeconometrics using stata, Revised. Stata Press, College Station

37. Freese J, Long JS (2014) Regression models for categorical dependent variables using stata, 3rd edn. Stata Press, College Station

38. Gilbert GN, Troitzsch KG (2005) Simulation for the social scientist. Open University Press, London

39. Epstein JM, Axtell R (1996) Growing artificial societies: social science from the bottom up. Brookings Institution Press, Washington, DC

40. Lewe J-H, DeLaurentis DA, Mavris DN (2004) Foundation for study of future transportation systems through agent-based simulation. In: 24th international congress of the aeronautical sciences, pp 1-10

41. Fontaine CM, Rounsevell MDA (2009) An Agent-based approach to model future residential pressure on a regional landscape. Landsc Ecol 24:1237-1254. https://doi.org/10.1007/s10980-009-9378-0

42. Siebers PO, MacAl CM, Garnett J et al (2010) Discrete-event simulation is dead, long live agent-based simulation! J Simul 4:204-210

43. Hosseinali F, Alesheikh AA, Nourian F (2013) Agent-based modeling of urban land-use development, case study: Simulating future scenarios of Qazvin city. Cities 31:105-113. https://doi.org/10.1016/j.cities.2012.09.002

44. Uhrmacher AM, Weyns D (2009) Multi-agent systems: simulation and applications. CRC Press, Boca Raton

45. Rebaudo F, Dangles O (2013) An agent-based modeling framework for integrated pest management dissemination programs. Environ Model Softw 45:141-149. https://doi.org/10.1016/j.envsoft.2012.06.014

46. Chen Y, Zhao HV (2020) Analysis of super users in information diffusion. Behavior and evolutionary dynamics in crowd networks. Springer, Singapore, pp 107-130

47. Wilensky U (1997) Netlogo Rumor Mill model

48. Huang N-T, Wei C-C, Chang W-K (2007) Knowledge management: modeling the knowledge diffusion in community of practice. Kybernetes 36:607-621. https://doi.org/10.1108/03684920710749703

49. Allen TJ (1984) Managing the flow of technology: technology transfer and the dissemination of technological information within the R \& D organization. MIT Press, Cambridge

50. Wang J, Gwebu K, Shanker M, Troutt MD (2009) An application of agentbased simulation to knowledge sharing. Decis Support Syst 46:532-541. https://doi.org/10.1016/j.dss.2008.09.006

51. Schlesinger S, Crosbie RE, Gagne RE et al (1979) Terminology for model credibility. SIMULATION 32:103-104

52. Sargent RG (1999) Validation and verification of simulation models. In WSC'99. 1999 winter simulation conference proceedings. "Simulation-A Bridge to the Future" (Cat. No. 99CH37038). IEEE, Phoenix, AZ, USA, pp 39-48

53. Law AM, Kelton WD (1991) Simulation modeling \& analysis, 2nd edn. McGraw-Hill, Singapore

54. Kleijnen JPC (1995) Verification and validation of simulation models. Eur J Oper Res 82:145-162. https://doi.org/10.1016/0377-2217(94)00016-6

55. BPS (2012) Flores Timur in Figures 2012. BPS-Statistics of Flores Timur Regency, Larantuka

56. Rosidin U, Rahayuwati L, Herawati E (2020) Perilaku dan Peran Tokoh Masyarakat dalam Pencegahan dan Penanggulangan Pandemi Covid-19 
di Desa Jayaraga, Kabupaten Garut. Umbara Indones J Anthropol 5:42-50. https://doi.org/10.24198/umbara.v5i1.28187

57. Patrick JM, ljah CN (2012) Adult and non-formal education programmes of non-governmental organizations for Poverty Alleviation in Nigeria: what can be learnt from the practice? J Educ Pract 3:1-7

58. Vastradmath $N$ (2015) The role of corporate social responsibility for an inclusive growth in the society: "The practice of CSR in the context of rural development in India." Int J Sci Res Publ 5:423-427

59. Walker J, Sarkodie G (2019) Adult education as corporate social responsibility in Canadian mining companies: performing the good citizen for greater self-regulation. Comp A J Comp Int Educ 49:298-317. https://doi. org/10.1080/03057925.2017.1403890

60. Agboeze MU, Nwankwo EA (2018) Actualizing Sustainable Development Goal-11 in rural Nigeria: the role of Adult Literacy Education and Tourism
Development. Bus Strateg Dev 1:180-188. https://doi.org/10.1002/bsd2. 21

61. UN, ADB, UNDP (2017) Asia-Pacific Sustainable Development Goals outlook. Bangkok

62. Srithi K, Balslev H, Wangpakapattanawong P et al (2009) Medicinal plant knowledge and its erosion among the Mien (Yao) in northern Thailand. J Ethnopharmacol 123:335-342. https://doi.org/10.1016/j.jep.2009.02.035

\section{Publisher's Note}

Springer Nature remains neutral with regard to jurisdictional claims in published maps and institutional affiliations.
Ready to submit your research? Choose BMC and benefit from:

- fast, convenient online submission

- thorough peer review by experienced researchers in your field

- rapid publication on acceptance

- support for research data, including large and complex data types

- gold Open Access which fosters wider collaboration and increased citations

- maximum visibility for your research: over 100M website views per year

At BMC, research is always in progress.

Learn more biomedcentral.com/submissions 